МОСКОВСКИЙ ГОСУДАРСТВЕННЫЙ УНИВЕРСИТЕТ имени М.В. ЛОМОНОСОВА

ЭКОНОМИЧЕСКИЙ ФАКУЛЬТЕТ

КАФЕДРА ПОЛИТИЧЕСКОЙ ЭКОНОМИИ

Экономика для менеджеров

Книга I

Учебник

Под редакцией Пороховского А.А., Тенякова И.М.

Москва, 2019

Формат 60x84/16

Кол-во усл. листов - 31,4

Твердая обложка

Тираж 400 шт.

УДК 330.1

ББК 65.02

ISBN 978-5-6043125-7-5

(c) Кафедра политической экономии экономического факультета МГУ имени М.В. Ломоносова, 2019

(C) Издательство «КнигаМемуар», 2019

\section{Экономика для менеджеров}

\section{Kнига I}

Учебник

Под редакцией Пороховского А.А., Тенякова И.М. 
Рецензенты:

Сорокин Дмитрий Евгеньевич - доктор экономических наук, профессор, член-корреспондент РАН, научный руководитель ФГБОУ ВО «Финансовый университет при Правительстве РФ»;

Рязанов Виктор Тимофеевич - доктор экономических наук, профессор, заслуженный работник высшей школы РФ, заведующий кафедрой экономической теории экономического факультета ФГБОУ ВО «Санкт-Петербургский государственный университет».

Экономика для менеджеров: учебник. В 2-х книгах. Книга І. / под ред. А.А. Пороховского, И.М. Тенякова. - М.: Издательство «Книга-Мемуар», 2019. - 540 с.

Учебник ЭКОНОМИКА ДЛЯ МЕНЕДЖЕРОВ подготовлен в рамках образовательных стандартов нового поколения МГУ имени М.В.Ломоносова для студентов направления МЕНЕДЖМЕНТ, обучающихся по программе бакалавров. Он состоит из двух книг. Первая книга содержит теоретические основы изучения экономики и анализ деятельности фирм на микроуровне национальной экономики. Вторая книга посвящена макроэкономическим вопросам функционирования компаний и роли государства, месту национальной экономики в мировом хозяйстве в условиях четвёртой промышленной революции.

Учебник может быть использован в вузах России и других стран в рамках соответствующих образовательных программ, включая программы неэкономического профиля; в школах бизнеса и управления, а также для дополнительного образования в различных формах.

Материал учебника формирует основы для освоения всего комплекса дисциплин, позволяющих стать высококвали- 
фицированным управленцем в различных сферах работы менеджеров.

Учебник может быть полезен для всех, кто интересуется вопросами управления и экономики, проблемами повышения эффективности деятельности российских компаний в условиях растущей конкуренции на мировых рынках в XXI веке. 